in some parts they may be referred to the Tertiary period, and also the subsidence, at least of the western part of the basin, is probably of the same age. Mr. A. M. Nikolski has connected Balkhash with the Han-hai, not with the Turkestan basin, believing that the Han-hai with Balkhash was isolated before the separation of the Aralo-Caspian sea from the Siberian, and certainly no Aralo-Caspian deposits occur for some distance west of Balkhash. Marks of high water are found on the north-west of the lake Ioo $\mathrm{ft}$. above the present level, and therefore the lake must at one time have covered a large area to the south and east. According to Golubief, the lakes Sasylkul, Uyali, and Ala-kul formed one lake within the memory of man, and the difference of level between Ala-kul and Ebi-nor is only $25 \mathrm{ft}$. During last century there was a long period of desiccation, but for the last twenty years the lake has been rising. The water of the western part of the lake, into which the Ili pours considerable volumes, is quite sweet, but it is brackish in the small bays and channels.

Floral Regions of Siberia.-In the Bulletin of the Imp. Academy of Sciences in St. Petersburg, No. 14, I9I2, Mr. N. I. Kuznetsof proposes a division of Siberia into floral regions, after discussing those of Ledebour, Korzhinski, and Tanfilyef. A line following the watershed between the Yenesei and Lena, approximately coinciding with geological and climatic boundaries, prolonged northwards to the watershed between the Khatanga and Anabara, and southwards to the mountains at the southern end of Lake Baikal, divides the principal regions into eastern and western parts. In the western section of the forest area arboreal species of the Altaic or western Mongolian centre prevail, in the eastern those of the Manchurian centre. Beyond the limit of arboreal vegetation determined by Siberian travellers, notably Middendorff, is the Arctic zone, its eastern part characterised by species and even families common to the Arctic regions and America, and also by representatives of the Alpine flora of the Stanovoi and Verkhoiansk ranges. Kamchatka and the Okhotsk coast down to the north of Sakhalin constitute a separate division, in which Altaic forms, are absent, and peculiar species of trees, Picea ajanensis, Abies nephrolepis, and Betula Ermanni, occur. Foliage trees are seldom found in Siberia except in the Amur district, where Tertiary forms exist which perished in other parts of Siberia during the cold period contemporaneous with the Ice Age of Europe. The Alpine region is confined to islands and bare summits amidst the sea of coniferous forests, in the Verkhoiansk and other ranges. East of Lake Baikal Pinus pumila occurs, species which thrive on rocky peaks are few, and the flora passes at the north-eastern extremity of the Yablonovoi range into the Arctic flora. Lastly, there are two areas of steppe-lands, one in the west between the southern limit of the taiga, and the watershed between the Arctic ocean and the Aralo-Caspian depression, the other embracing the basins of the Shilka, Argun, and the Upper Amur, as far as Albazin.

Natives of Siberia.-According to Mr. S. Patkanof (Zapiski of the Imp. Russ. Geogr. Soc., Statistical Section, vol. xi., No. 1), the natives of Siberia number 870,536 , of whom 442,459 are males. This sex generally preponderates, except in a few small tribes. The most numerous are the Buriats, who number 288,599 . As regards governments, Yakutsk contains the largest number of natives, namely 235,623 , and they constitute $87^{\circ} 5$ per cent. of the total population. In Transbaikalia and Irkutsk they are also numerous, while they are few in the Amur province. There are, however, districts of Siberia where the natives are almost NO. 2280 , VOL. 91$]$ all the population. The other inhabitants of Siberia, chiefly Russians, number $4,889,633$, so that the natives constitute only about $\mathrm{I}_{5}$ per cent. of the total population.

\section{METEOROLOGICAL REPORTS AND SUMMARIES.}

$A$ USEFUL discussion of the cloudiness and sunshine of North America, by $\mathrm{Mr}$. A. Gläser, is contained in Aus dem Archiv der Deutschen Seewarte, vol. xxxv., No. I, based on published data from available sources. The subject is treated in considerable detail as regards time and place, and is illustrated by copious tables and diagrams. The few following points may be mentioned among the general features referred to. In the westward districts westerly winds bring most cloud, clear sky in summer being due to the higher saturation point of the air. Eastward of the Rocky Mountains the sky is clearer, but with northerly and southerly winds the spring is the most cloudy season. The winter barometrical minimum in the North Atlantic causes easterly winds in the eastern States, and these, mixing with the relatively warm air of the coast, produce a large amount of cloud. The high pressure in the south-east in autumn causes clear weather; in the south the greatest clearness occurs towards the end of winter. In the south-west of the United States and western Mexico the warm winds of the Gulf of California cause much cloud in summer; the clearest season is spring, and the dry northerly winds of the northern portions bring clear weather in autumn. The most bright sunshine is found in the south-west of the continent, and the least in the northwest and north-east, where the sun's power is naturally much weaker. In the region east of the Rocky Mountains there is comparatively little change in proceeding from south to north.

The Rev. L. Froc, S.J. (director of the Zi-ka-wei Observatory, near Shanghai), has issued the first part of a useful discussion of the rainfall in China during eleven years, 1900-ro; the paper also includes data for a number of stations for shorter periods. Full particulars are given respecting the geographical position and surroundings of each station. In addition to the sums for individual months and years, and means for seasons and for the whole period, interesting details are given with reference to the variability of rainfall and unusual falls in the yearly, monthly, and daily periods, but the general discussion of the data and preparation of a rainfall map are reserved for the second part of the paper, to be published later on. It is remarked that the rainfall is not so excessive as in some neighbouring countries, e.g. the Philippine Archipelago. The following are among the heaviest of the yearly falls :-Hongkong, $2473 \mathrm{~mm}$., in I902; Fouchow, $2572 \mathrm{~mm}$., in 1906; Sanchoei, $2760 \mathrm{~mm}$., in 1907; Pakhoi, 2691 mm., in I908; all in the south-east of China. The greatest daily fall was $320 \mathrm{~mm}$. (12.6 in.) at Pakhoi. The diagrams show that in all districts the greatest rainfall occurs during the summer half-year.

The Commonwealth Central Weather Bureau has issued an average rainfall map of Tasmania, the fifth of the series showing the annual rainfall distribution of Australia. The most striking feature of the map is the great variation between the greatest and least average falls, viz. I7.9 in. at Beaufront, in the midland district, and ${ }^{1} 5.8$ in. at Mt. Lyell, on the west coast. This coast is exposed to the moist westerly winds, and condensation is favoured by physiographic conditions, the result being a mean annual fall of 88.7 in. for the whole district generally. On the east coast the annual 
mean is 32.7 in. For a large area (about 3000 square miles) no records are available.

The annual report of the meteorological observatory of the Grovernment-General of Korea for the year I9II (Dr. Y. Wada, director) contains valuable observations taken three times daily at ten stations, with carefully prepared summaries. Weather conditions and special occurrences are denoted by international symbols, and the instruments and methods of observation are similar to those at meteorological stations in Japan, and, consequently, are all that can be desired. The absolute maxima of air temperature ranged between $88.3^{\circ} \mathrm{F}$. at Fusan and $9^{2} \cdot 8^{\circ}$ at Chemulpo, both in August, and the absolute minima between $-16 \cdot 1^{\circ}$ at Ping-yang and $15.3^{\circ}$ at Mokpo, both in January. The yearly rainfall varied from $33.3 \mathrm{in}$. at Song-chin to 76.8 in. at Fusan. The largest amount of sunshine was 2642 hours, at Ping-yang, being 60 per cent. of the possible quantity.

A report on the Mariout district, by Mr. A. L. P. Weedon, in Nos. 72 and 73 of The Cairo Scientific Journal, is of much interest, both from an agricultural and from a meteorological point of view. The district, which consists of a long strip of land west of Alexandria, was in ancient times famous for.its fertility, but at present it is for the most part barren and waste, barley being practically the only crop grown, in some parts only, and this is dependent on the somewhat precarious winter rains. The rainfall seems to differ but slightly from that of Alexandria, which averages $220 \mathrm{~mm}$. (8.7 in.) per annum. The climate depends on the temperature of the Mediterranean and the general atmospheric circulation, and from numerous quotations from ancient and modern writers it is concluded that there is no reason to believe that either of those factors, or the rainfall, has changed since Roman times. The author states that the land is capable of producing more profitable crops in the hands of more efficient cultivators, who by the employment of scientific methods could either give it a better or more regular water supply, or make a better use of the existing moisture of the soil, e.g. by a system of dry-farming (economising the rainwater by digging trenches before the rainy season), assisted by wells and cisterns, many of which already exist.

The Austrian Meteorological Institute has published part v. of its valuable "Klimatographie" of that country, referring to the mountainous province of Salzburg. Climatologically, Salzburg belongs to the Central European district, but owing to the Alps it is subject to many marked modifications. The portion on the northern side of the limestone Alps, being exposed to the north and north-west winds, has a decidedly damp and rainy character, with the peculiarities of the West European climate. But between the limestone and central alpine chain lies a zone of a continental, dry character, with stagnant masses of air (Luftseen) in the valleys, in winter excessively cold, and relatively warm in summer. In the Lungau district, Salzburg participates in the rough, inhospitable climate of the upper Mur valley. The author, Dr. A. Fessler, adopts in the main this general subdivision of the climatic conditions in his elaborate discussion, dealing with each district in great detail, and with full consideration of the effects of aspect and altitude on temperature, rainfall, and climate generally. The discussion is based on observations made at stations connected with the Central Institute, but the author is handicapped bv the paucity of data in many points of climatological importance; from this point of view Salzburg compares unfavourably with other alnine districts; complete observations for, say, twenty years and upwards onlv exist for comparatively few stations.

NO. 2280 , VOL. 9I]

\section{GREAT ADVANCE IN CRYSTALLO-} GRAPHY. ${ }^{1}$

CRYSTALLOGRAPHY has made such remarkable progress during the last few months, and the position at the present moment is so interesting, that it was considered opportune to review it in a discourse from this historic lecture-table.

Overwhelming evidence has now been brought forward that a crystal is endowed with a definitely organised structure. $^{2}$ In the crystal of a pure substance we are dealing with a chemical element or compound, and if with the latter it may be of any grade of complexity, from a very simple binary compound to a most highly complicated one composed of a large number of atoms. If the crystal be that of an element the structure is obviously composed of the similar atoms of that element, while if it be a compound we have a structure composed of atoms of as many kinds as there are chemical elements present combined in the substance, and in the same relative proportion as is expressed by the chemical formula of the substance. In the case of a compound, moreover, the structure may also be considered to be that of the molecules of the substance, for they or a simple arrangement of a small number (group) of them form the grosser units of the structure, whilst the atoms are the ultimate units.

Suppose we now represent this molecular or polymolecular grosser structural unit by a point, and that such point be analogously situated within each unit. The essence of crystal structure then is that these points are so arranged in space that if they are joined along the three directions of space by imaginary lines the latter form a "space-lattice" (German, "Raumgitter"), each unit cell of which may be conceived to be the "brick" already alluded to in the earlier part of the lecture, and the domicile of the chemical molecule or group of molecules (indeed, it is immaterial whether the points are considered as placed at the corners or in the centres of the cells) or, in the case of an elementary substance, of a group of similar atoms. We may, therefore, define a crystal as follows:-

"A crystal of any definite chemical substance consists of a homogeneous arrangement of grosser units of matter, each consisting of one chemical molecule or a small group of molecules of the substance, and the kind of arrangement is such that these grosser units are all identically (sameways, parallel-wise) orientated, and that their analogously chosen representative points, one from each such grosser unit, form a space-lattice (Raumgitter)." 3

There are fourteen kinds of space-lattices, slides of several of which are exhibited on the screen. Three possess full cubic symmetry, two are tetragonal, four are endowed with rhombic symmetry, and two are monoclinic; while triclinic, trigonal, and hexagonal crvstals have each one space-lattice corresponding to their type of symmetry. In every case it is the full (holohedral) svmmetry of the system which is present, no space-lattice possessing merely the lower desree of svmmetry corresponding to one of the socalled hemihedral or tetartohedral classes of the syctem in question.

Now in the solid crystal, not only are the grosser

1 From a disconrse delivered at the Royal Institution on Friday, March 14 by Dr. A. F, H. Tutton. F.R.S.

2 This was very fully illustrated by numerous experiments during the first portion of the disccurse.

Since this lecture was delivered (March $\mathrm{r}_{4}$ ) and printed hy the Royal Inctitution, a paper by Prof. Thendore W. Richards, of Harvard Universitv. has appeared in the rournal of the American Chemical Society for Anril (vol. xxxv., p. "38r), in which he shows that his theory of compressihle atoms leads to "crystal units" of precisely the molecular or polymolecular character described in this lecture. He supposes such crystal units to be the entities necessary to relieve metastable supersaturation, and their centres to form the points of the crystal space-grating, assumptions with which the lecturer obviously fully concurs. 